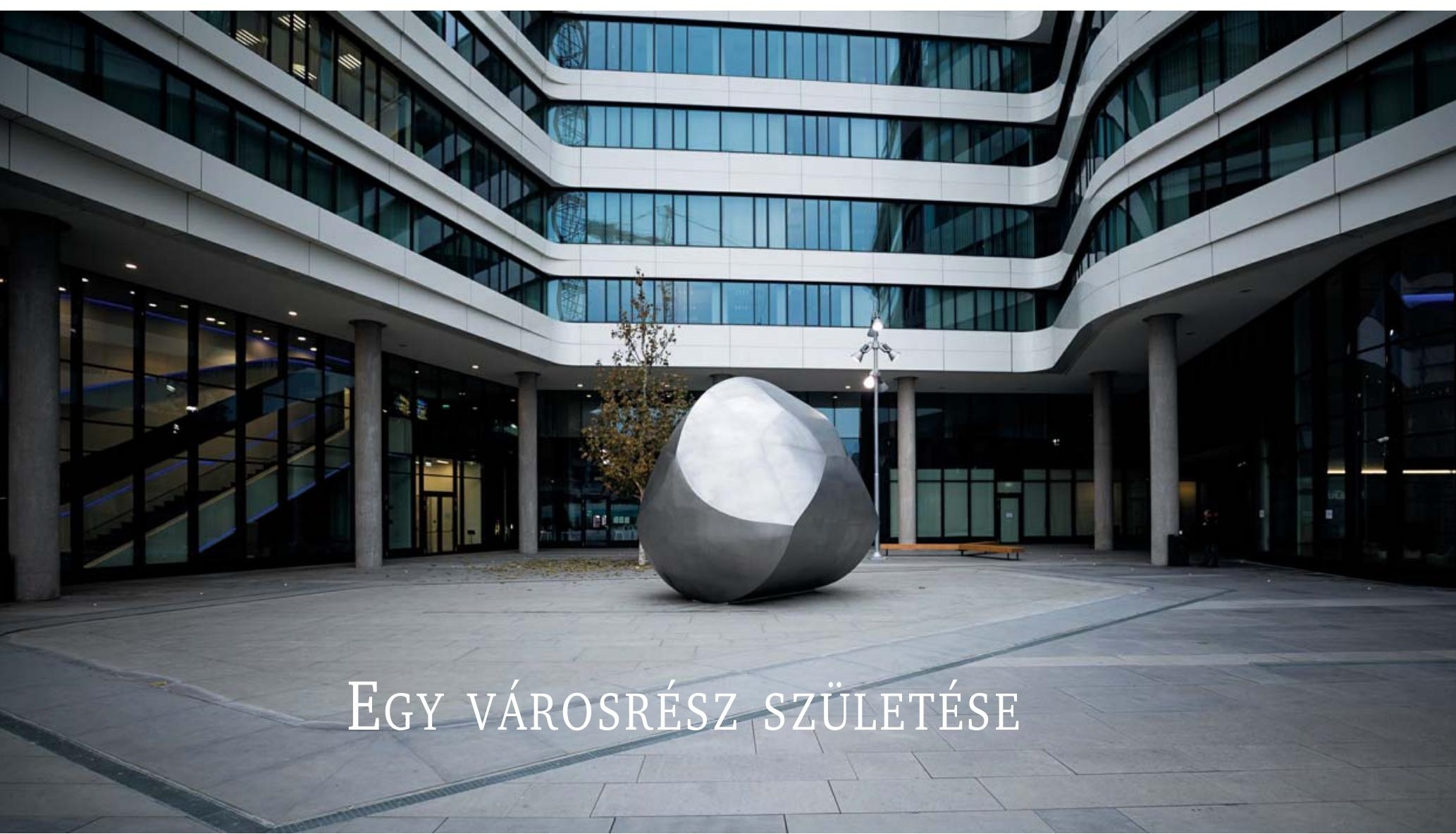

Józsefváros 2000-2020

A Corvin Sétány Program Budapest egyik legnagyobb, városrészméretű megújítási projektje lett az elmúlt 20 év alatt, új közterületek születtek, új épületek, új életmódok tapadtak meg a Józsefvárosban. Miben mérhető az átalakulás sikere? Az volt a kérdés 2000-ben, hogy Budapest belvárosában születhet-e egy új városrész. A városalkotó struktúrák milyen mértékig írhatók újra? Ma úgy tünik, hogy a közvetlen és a tágabb környezet befogadta az új közterületeket, pezsgő városi élet alakult ki, amelynek az új házakban élők és dolgozók, a környékbeliek és a fővárosiak is haszonélvezői. [1] A cikk azt járja körül, hogy a projekt 2000-ben kitüzött céljai hogyan valósultak meg társadalmi, gazdasági szempontból, illetve a környezet alakításának vonatkozásában. A résztvevők együttműködése volt az egyik kulcstényező a fejlesztés elveinek és céljainak szolgálatában, a másik a kialakított „folyamatszabályozási rendszer”, mely képes volt az állandó változásokat adaptálni a projektbe. A kezdeti állapotok bemutatása mellett ezért a cikk a városalakító folyamatra koncentrál, annak szereplőire, lépéseikre, arra, hogy a program napjainkban látható eredményeinek létrehozásában az összehangolt közös erőfeszítések hozták meg az eredményeket.

\section{Felütés, hipotézis}

Egy város „... azért oly csillogó és vitális mindig, mert az emberek nap mint nap megújítják, [...] a reménység és a várakozás terévé alakítják, [...] találkozókat keresve, és ennek nincs köze az építészethez. Ezek azok az érzelmek, amelyek a városokba vonzanak minket. A legtökéletesebben tervezett helyek sem tudják ezt nyújtani." [12]

A Corvin Sétány (Szigony) Program fejlesztése során annak a keresése zajlott, hogy milyen mértékben lehet egy város - egy történeti belváros - struktúráit újraírni. A 19. század utolsó évtizedeinek mindent elsöprő növekedése rajzolta meg a Nagykörúton túli városrészeket, határozta meg hangulatukat. A főutak menti bérházaknak és a mellékutcák spekulációs házainak közel sem azonos minőségű historikus építészete, az erős társadalmi anakronizmusok emlékezetünkben a 21. század elejére együtt élő szövetté szelídültek. A Corvin mozi mögötti 
negyed utolsóként, a legkisebb intenzitással épült be a 19-20. század fordulóján, a rossz - mocsaras - talajadottságok miatt, ezért kerültek ide kertek, mezőgazdasági és kisiparos-épületek. Budapest belvárosának 5500 elemből álló eklektikus „épületgyüjteményének” egyik legheterogénebb területe volt, erre a területre csapott le az '56-os forradalom öröksége és a szocialista korszak városrekonstrukcióhoz kapcsolódó intézkedéssorozata is. [13] ták meg a város fejlődésének irányát, a belső városrészek egyértelmúen nyertesei voltak a folyamatoknak.

Józsefvárosban, bár Pest belvárosában fekszik, minden szempontból jó kapcsolatokkal, mégis ellentétes hatások érvényesültek, a felgyorsult társadalmi mozgások során a képzettebb, anyagilag erősebb rétegek elköltöztek, a józsefvárosi „image” mélyponton maradt, az emberek elvesztették még a maradék, jövőbe vetett hitüket is. [3] A rendszerváltásig, illetve az azt követő időben

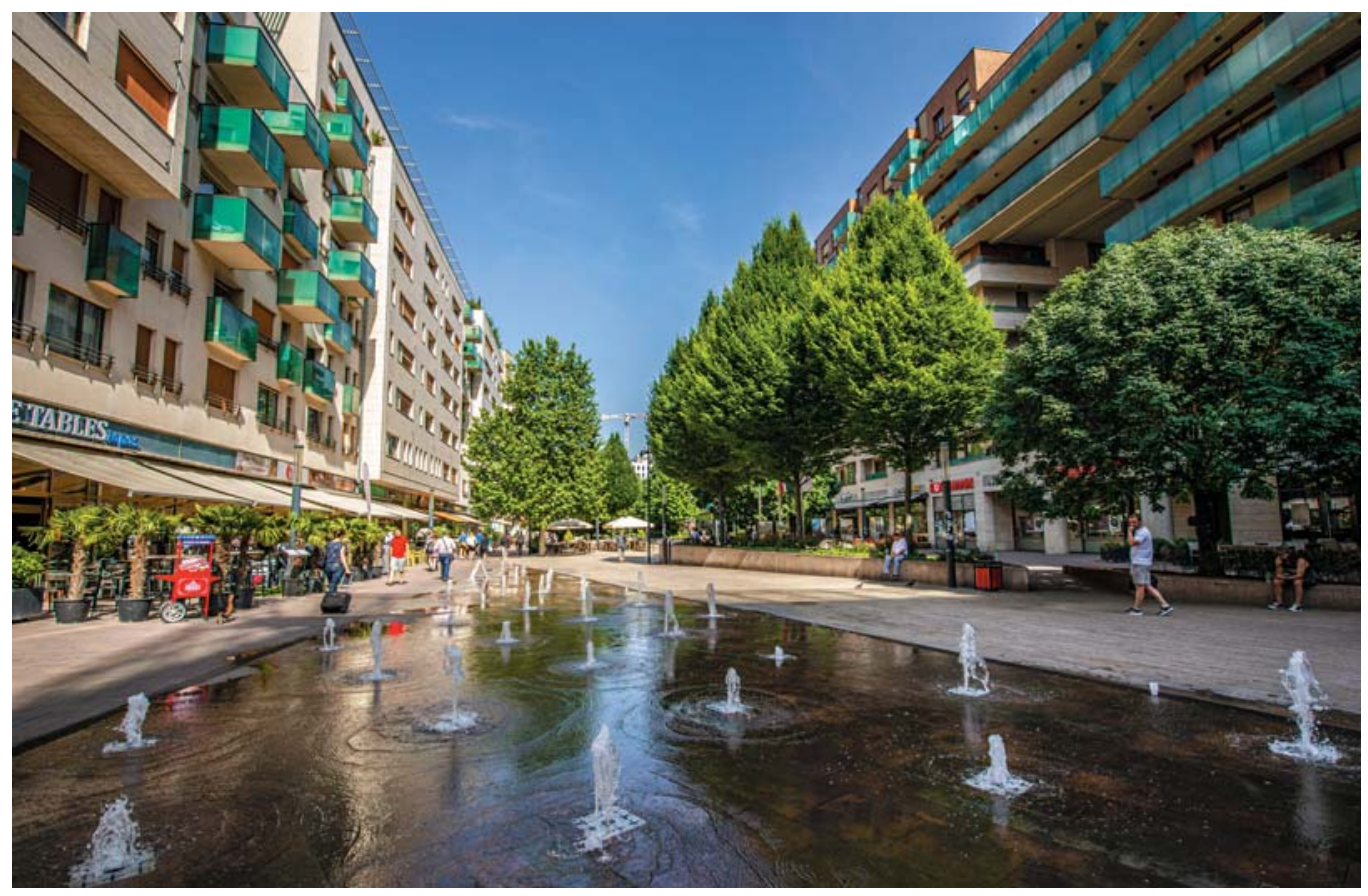

Az a kérdés merült fel, hogy ezt a többször kiürült, városléptékű térbeli struktúrát érdemes-e védeni, vagy lehet-e újraírni a történetét? Gondolkozásunkat az a felelősség hatotta át, hogy Józsefvárosnak szüksége van új történetekre. Természetesen nem mindegy, hogy milyenek lesznek a házak, az utcák és a terek, de a lényeg az élet visszatérése. Az volt a feladatunk, hogy megleljük a módját, hogyan lehet a városrész sokszínűségét megőrizve új színeket keverni hozzá, hiszen a huszadik század végére Józsefvárost egyértelműen a társadalmi és fizikai leromlás határozta meg. Ekkor vált világossá számunkra, hogy amikor kialakítjuk a programot, akkor a városi lét alapjaira kell koncentrálnunk: az együttműködésre, a városrész eltartóképességének növelésére. [2]

\footnotetext{
A kezdetek

A Corvin Sétány Program megértéséhez érdemes a fejlesztés kezdeteit felidézni. Budapest 1989 után gyors változásokon ment át, a város társadalmi szerkezete erősen differenciálódott. A gazdasági átalakulásban közvetlenül részt vevő rétegek anyagi helyzete javult, míg a közvetlenül nem érdekelt rétegek helyzete romlott. Ezek a gazdasági-társadalmi folyamatok alapvetően határoz-
}

összeszedett hátrányaival a kerület nem tudott egyedül megküzdeni. Az önkormányzat ezt 1995-ben ismerte fel, és fogadott el városrehabilitációs stratégiákat, melyekben először fogalmaztak meg a városépítészeti javaslatokon túlmutató, sokrétü eszközrendszert, amely alkalmas az összetett társadalmi-gazdasági térben eredményeket elérni. [16], [15]. Mind a kerület, mind a főváros legrosszabb helyzetben lévő területeként határozták meg Középső-Józsefvárost ezek a stratégiák, és ennek a helyzetnek az alapvető megváltoztatása érdekében a 10000 db-os, leromlott állapotú és lakásfeladatokra jelentős mértékben alkalmatlan önkormányzati „lakásállomány” lecserélését jelölték meg feladatként. [17]

A 2000-es évek eleji gazdasági, pénzügyi változások és az EU-csatlakozás jelentős ingatlanpiaci hatásokkal bírtak a fóváros belső területeire. Attól lehetett félni, hogy Józsefvárost kedvező városszerkezeti pozíciója ellenére elkerülik a változások, és felgyorsul a leromlási folyamat. [8] Ekkor döntött arról a Józsefvárosi Önkormányzat, hogy Középső-Józsefváros városrehabilitációjának felgyorsítása érdekében összefogott programot kezdeményez a Corvin mozi és a Szigony utca közötti 22 hektáros területen. [1] 


\section{A folyamatszabályozási rendszer}

A Corvin Sétány városrehabilitációs program a Rév8* terméke. [1] Az 1997-ben alapított kerületi városrehabilitációs társaság 2000-ben dolgozta ki a program alapjait, amely a városrehabilitáció kiterjesztett értelmezésére épült: a folyamatnak a városalakító - társadalom, gazdaság, természeti környezet, épített környezet - tényezők együttes megújítására kell koncentrálnia. [20] Ehhez először átgondoltuk céljainkat, a felhasználhatórendelkezésünkre álló eszközöket, hiszen helyzetünk ebben az időszakban sokkal nehezebb volt, mint a szomszédos kerületeké. Olyan folyamatszabályozási rendszert cioökonómiai problémákkal terhes városrészek megújítása nem lehetséges merev múszaki megoldásokra összpontosító eszközökkel. [21] A folyamat irányítását, lebonyolítását, a projektmenedzseri feladatokat 2009-ig a Rév8 Zrt. vitte teljes vertikumában, vagyonkezelési szerződés és az önkormányzattól széles körben átvett jogkörök alapján, mind az önkormányzat, mind a befektető számára biztosítékot jelentve. A társaság aktívan vett részt az előkészítésben - a megvalósítás feltételeit biztosító rendeletek, szerződések kialakításában, a pályázatok elkészítésében, a pénzügyi tervezésben - és a megvalósításban is.

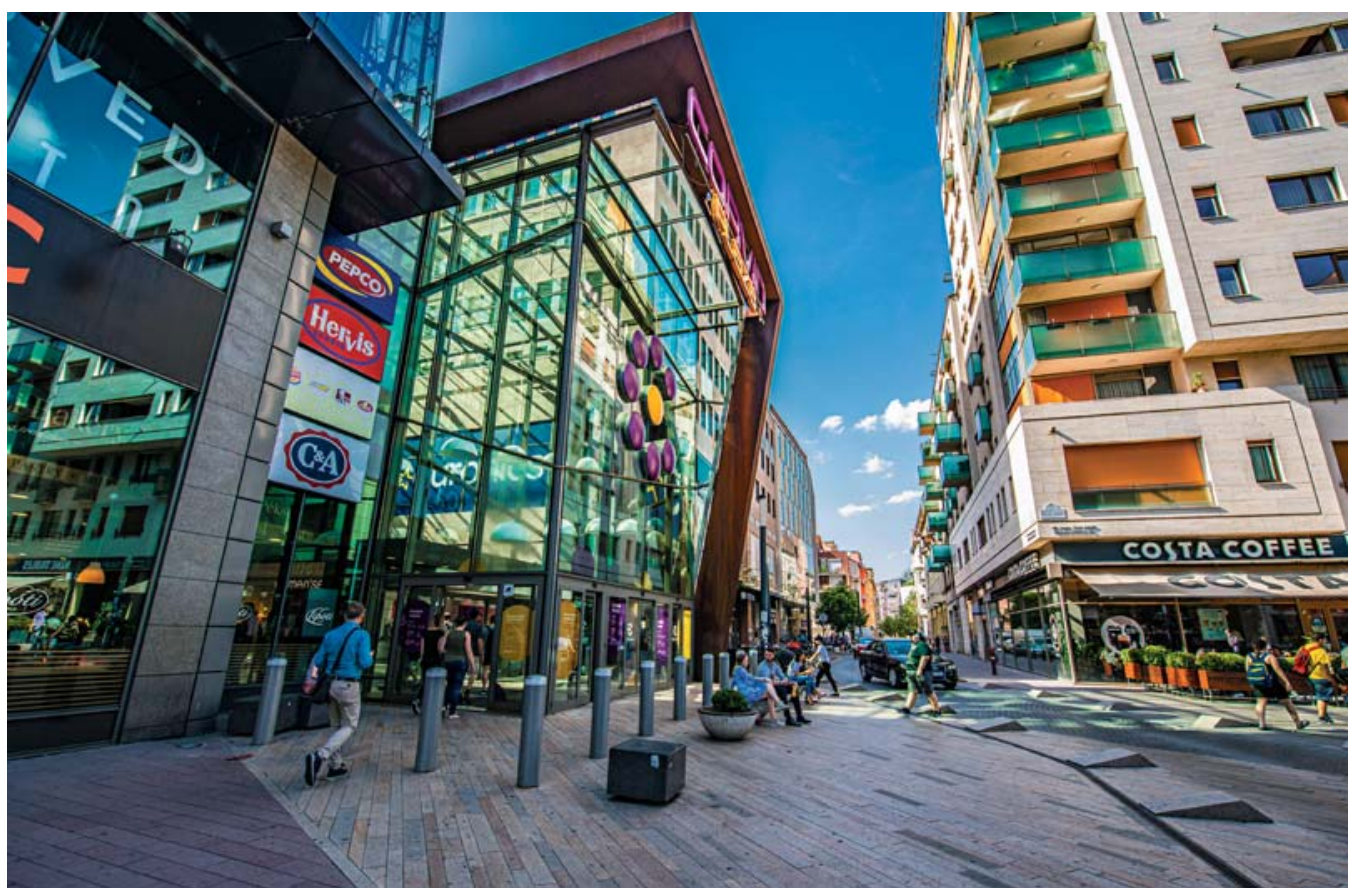

alakítottunk ki, amelyet a közösségi értékdöntések vezettek, és a visszajelzések alapján a változásokra reagálva lehetett az adott körülményekhez igazítani döntéseket. A felhasznált szakmai tartalmak között a piackutatás, a jövőkutatás, a makrogazdasági helyzet modellezése mellett szerepelt a hagyományos településrendezés mint eszköz, valamint az önkormányzati intézmény- és normaalkotás (önkormányzati normaalkotás, szervezeti fejlesztések), mert ezek csak együttesen tudták biztosítani a városrehabilitáció sikerének lehetőségét. Kulcselemként lehet azonosítani a hosszú távú gondolkodás intézményesítését is: az integrált projektmenedzsment-szervezet helyzetbe hozását, a felek számára biztonságot adó szerződéses rendszer megalkotását, amely a nagy időtáv miatt megjelenő kockázatok kezelésére helyezte a hangsúlyt. [22]

A projektmenedzsment-szervezet önmagában jelenítette meg az integrált megközelítést, interdiszciplináris stábot létrehozva. Ennek a szemléletnek a bevezetését a kortárs nemzetközi példák is igazolták: a komplex szo-
A Rév8 a kiköltöztetés igen érzékeny és összetett feladatát saját munkatársaival látta el, akik egyszerre voltak lakásügyi szakemberek, szociális munkások, ingatlanosok. Egyeztettek, tárgyaltak a lakókkal, hogy megtalálják a lakók élethelyzetének megfelelő megoldásokat, intézték a szükséges papírokat, a tisztázatlan bérlöi/jogi helyzeteket rendezték, felkutatták a kerületben a megfelelő lakásokat, közreműködtek a szerződéstől a költözésig. Ezzel a nagyon intenzív lakossági kapcsolattartással, együttmúködéssel és az empatikus hozzáállással lehetett a több mint 900 önkormányzati és társasházban lakó család elhelyezését 2009-ig úgy megoldani, hogy senki sem került rosszabb helyzetbe, mint ahol lakott, a komfort nélküli bérlakásokból sikerült mindenkit az eredetinél jobb állapotú komfortos lakásba költöztetni a kerületben. Az akcióterület zárt közössége eleinte idegenül tekintett a szervezetre, de lassan kialakult a bizalom, és ezt segítette elő a Práter utcai iroda nyitott, barátságos kialakítása, amely önálló helyként tudott működni a helyiek felé. Ez volt talán az egész folyamat legérzéke- 
nyebb, de talán legszebb része is egyben. A Rév8-ban mérnökök, építészek, közgazdászok mellett szociális szakemberek dolgoztak nagy számban, így személyesen tudtunk foglalkozni az emberekkel, éreztetve, hogy nem áldozatai a folyamatnak, hanem épp ellenkezőleg, a program fó célja az, hogy az ő életük is jobb minőség irányába mozduljon el. A társaság a személyes kommunikációra nagy hangsúlyt helyezett, a kollégák megismertek mindenkit a területen. Látható, hogy a Rév8 feladata jóval többet jelentett egyszerű szépészeti, városcsinosítási beavatkozásnál, mert nemcsak a házakkal, de az emberek életével is törődtünk. tekint sikernek - is része volt a projektmenedzseri feladatnak. A nagy projekt sikerét - a szerződés flexibilitását - mutatta az, hogy túlélte a 2008 őszétől a 2010-es évek elejéig tartó gazdasági válságot és az azt követő változásokat. A befektető szakmai elkötelezettségének köszönhetően a projekt folyamatosan épült, bár sebessége érezhetően csökkent. A 2014-re az önkormányzat vállalásainak 80-90\%-át teljesítette, és a befektető is elérte - a gazdasági változások ellenére - a több mint 70\%-os készültséget, és a felek aláírták a projekt befejezését biztosító megállapodást. A 2000-ben elindított Corvin Sétány Program közel 20 év alatt, 2020-ra készül el.

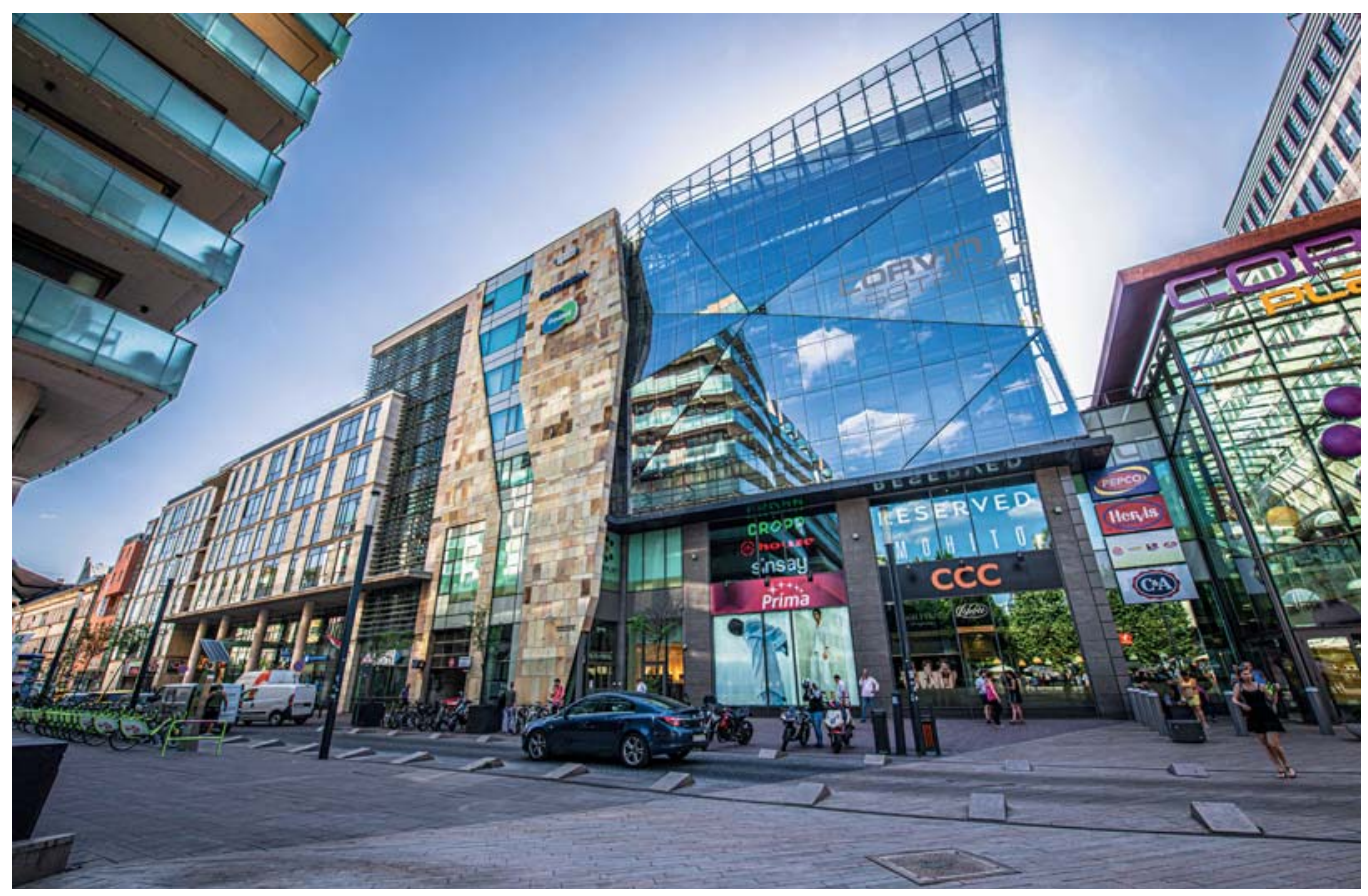

A szerződéses rendszer a szereplők hosszú távú együttműködésének másik megalapozója volt. Az önkormányzat 2001 után, a 2002-2003-as kétfordulós, nemzetközi nyilvános pályázat győztesével kötötte meg az együttműkködési szerződést. 2004 után ez a szerződéses rendszer biztosította a kapcsolatot a befektető - Futureal - és az önkormányzat között. A kerület alapvetően 10 éves együttmúködést kínált fel, nem egyszerű ingatlanadásvételi szerződést. A jogi környezetet több összekapcsolódó szerződés biztosította, melyek a hosszú megvalósítási idő igényeit, kockázatait, garanciáit rögzítették. A Rév8 a területet - mind fizikai, mind átvitt értelemben - fokozatosan adta át a befektetőnek úgy, hogy mindvégig biztosította a közösségi kontrollt.

A Rév8 múködése segítette elő az aktorok közötti párbeszéd, együttműködés és kommunikáció platformjának kialakítását, az eltérő szervezeti kultúrájú szereplők közötti szinkronitás biztosítását. A rugalmasan kialakított fejlesztési folyamat „célirányba” tartása - az önkormányzat 2000-ben fogadta el az alapvető értékeket, hogy mit

\section{A városi környezet}

A program indulásakor 2000-ben azon gondolkodtunk: lehet-e és hogyan a tervezőasztal mellett egy városrész vibráló, pezsgő légkörét előre megteremteni? Mi határozza meg az egyes városrészek sikerét, hangulatát, hiszen ez Jane Jacobs szerint főleg nem építészeti kérdés. [12] A 21. sz. elején van-e olyan korszellem, amely szervesen össze tud majd kapcsolódni a helyi lakókkal, az új épületekkel és együtt tud növekedni a városrésszel? Hogyan lehet az életet visszacsalogatni erre a területre? Hogyan lehet egy projekt eredményeinek hosszú távú fennmaradását elősegíteni, a városrész önfenntartó képességét megerősíteni?

Budapest belvárosának kötöttségei kemény várostervezési és építészeti kihívás elé állították a tervezőket. A Józsefvárosi Önkormányzat 2000-es indító döntésében az épített környezettel kapcsolatban alapvető értékeket fogalmazott meg, hogy a józsefvárosi identitás szempontjából fontos építészeti és városépítészeti értékek megőrzése mellett egy új egységes beépítés alakuljon ki, 
és az új épületek a fenntartható fejlődés alapelvének feleljenek meg.

A városfejlesztési (rehabilitációs) koncepcióval párhuzamosan készült a terület részletes városépítészeti terve, majd a szabályozási terve. A hagyományos tervezés idea $>$ tapasztalás $>$ tervezés $>$ megvalósítás - lineáris additív folyamatát lépéseinek statikus, lezárt jellege miatt esetünkben nem láttuk használhatónak. A fejlesztésfejlődés-tervezés lépéseinek meghatározására ezért nem egy lezárt lépésekből álló sort terveztünk, hanem egy olyan folyamatot, melynek egyes elemei nyitottak és befogadni képesek az időbeli változásokat. Az egyre bonyolultabbá és részletezettebbé váló, mégis statikus jellegü, a változásokat nehezen követni képes tervezés helyett egyszerú, nyitott folyamatot határoztunk meg, annak szabályaival és kapcsolataival. Az igazi kérdés az volt, hogy egy ilyen folyamat nyitottsága biztosítja-e az eredményt és annak építészeti minőségét.

A városépítészeti majd szabályozási terv a terület rehabilitációs városfejlesztési eszközökkel történő megújításának müszaki-építészeti, városrendezési-szabályozási talmazó sétánnyal egészítettük ki a terület struktúráját. A sétány vonalvezetését többlépcsős építészeti, értékvédelmi elemzéssel határoztuk meg különböző, a városszövetbe illeszthető alternatívák megvizsgálásával. A Práter utca és a Tömő utca közötti tömbök megosztása adta a beépítésre alkalmas méretet, amely hasonló a Nap utca és a Práter utca közötti beépítésekhez. A városépítészeti terv kialakításakor törekedtünk a történelem során létrejött esetleges formák utánzásának elkerülésére, a városszövet lényegi elmeit alapul véve határoztuk meg a kereteket. A hagyományos tömbforma átvétele mellett törekedtünk az épületek környezeti értékeinek javítására, a „fenntarthatóság” feltételeinek megteremtésére. A városszerkezeti rendszer kisebb, a struktúrát nem érintő beavatkozásai a kerületi csatlakozási pontok és hálózatok megőrzésével történtek. A városrész budapesti beágyazottságát alapul véve alakult ki a terület beépítési intenzitása, és a három funkcionálisan elkülöníthető területfelhasználási egység - városközponti-intézményi, lakó, intézményi-tudásközpont - biztosítja a városrész „24 órás" használatát.

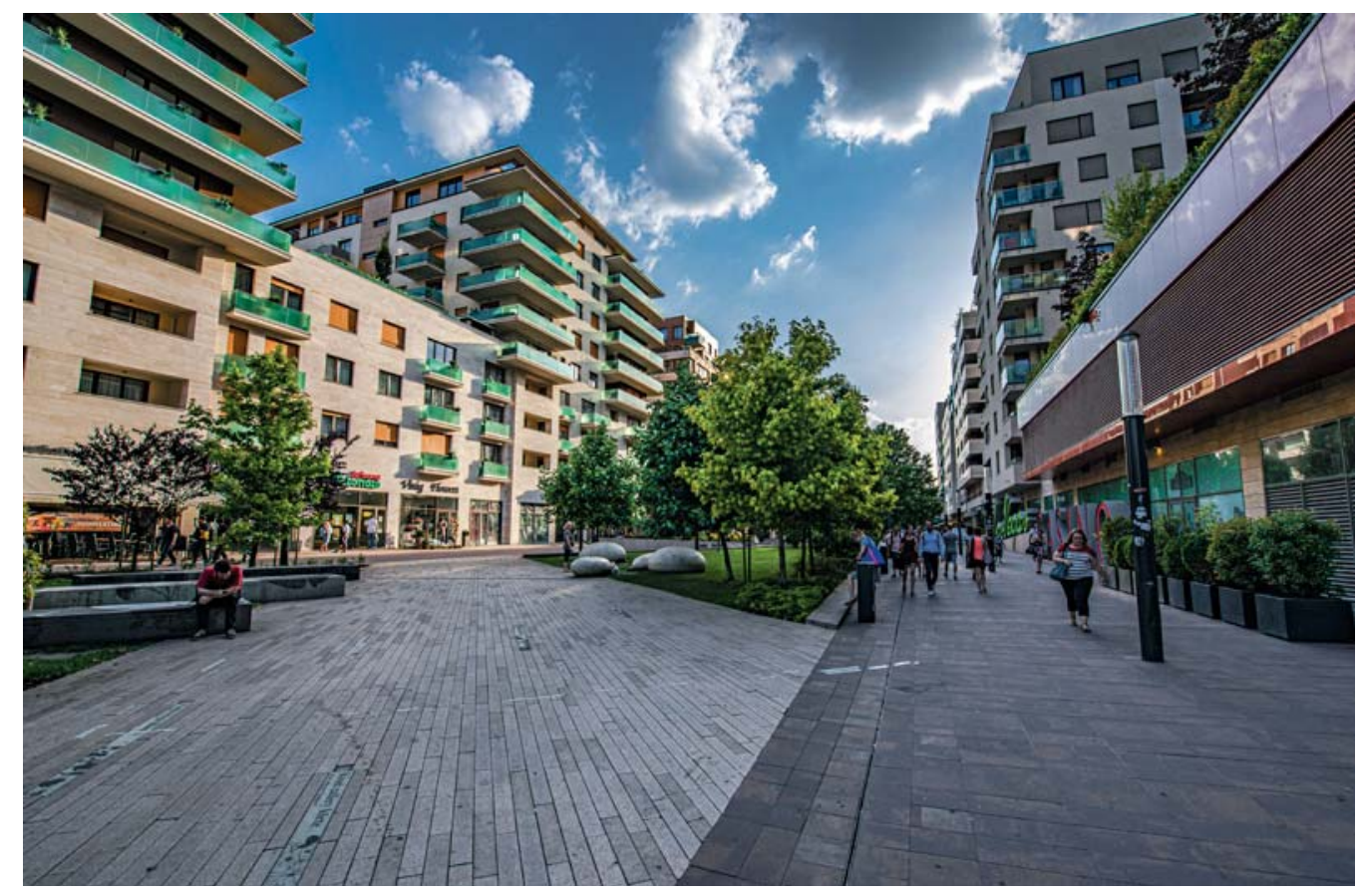

kereteinek a meghatározására, a közösségi alapértékek teljesülésének a biztosítására készült. A részletes állapotfelvétel alapján közösségi (kerületi önkormányzati) döntésekre alapozva határozta meg a megőrzendő értékeket, a fejlődés kereteit a lehetséges terhelésekkel, tekintettel Budapest fejlődésére és a folyamat piaci körülmények közötti megvalósíthatóságára. A tervezés során vizsgáltuk a jövő lehetőségeit és azok érdekeit is, akik a megvalósításban szerepet játszanak. A városszerkezetben alapvető strukturális beavatkozást terveztünk, a Corvin mozi mögött új, jelentős méretű zöldfelületet tar-
Az előkészítés, tervezés során óriási feszültséget kellett megoldani, amely az „értékvédelmi szemléletet” képviselők elvárása és a terület épületeinek valódi értéke között húzódott. [20] A tradicionális építészeti kialakítás egyes elveinek átvételén és a foutak menti peremek megőrzésén túl a beépítésre eszközként tekintettünk, hiszen a célunk nem az volt, hogy jelentős mennyiségú közpénzt költsünk ezeknek a közepes minőségú épületeknek a megújítására - a Nagykörúton kívüli városrészek közül ez volt a legheterogénabb minőségü -, hanem az, hogy a kerület megújulását mutató és elősegítő 
beépítés jöjjön létre. A megcélzott környezeti állapot a terület identitásának megőrzése mellett a városszerkezet újraírását, újrafogalmazáát vállalta fel, a városszövet hálózatainak megújitásával és gazdagitásával, jelentős mennyiségben minőségi közterületek és zöldfelületek felhasználásával.

A területen talált meghatározó épületállomány alapvetően két minőséget képviselt, a fóútvonalak melletti a Práter utcai, az Üllói úti - épületek építészeti, múszaki, funkcionális és lakhatási szempontból megfeleltek a tésével. [20] A BME Épitőművészeti Doktori Iskolája is foglalkozott a sétánnyal. Az épitészeti minőség biztositása érdekében a Futureal többlépcsős építészeti pályázatokon választotta ki a tervezőket. Több tucat magyar építészirodát előminősítve, tömbönként hirdetett meg 35 szereplős meghívásos pályázatokat. A sétány szabadtér-építészeti kialakítása kiemelt jelentőséggel bírt mind a Futureal, mind az önkormányzat gondolkodásában. Meghívásos pályázaton sikerült kiválasztani az angol tervezőt. *****

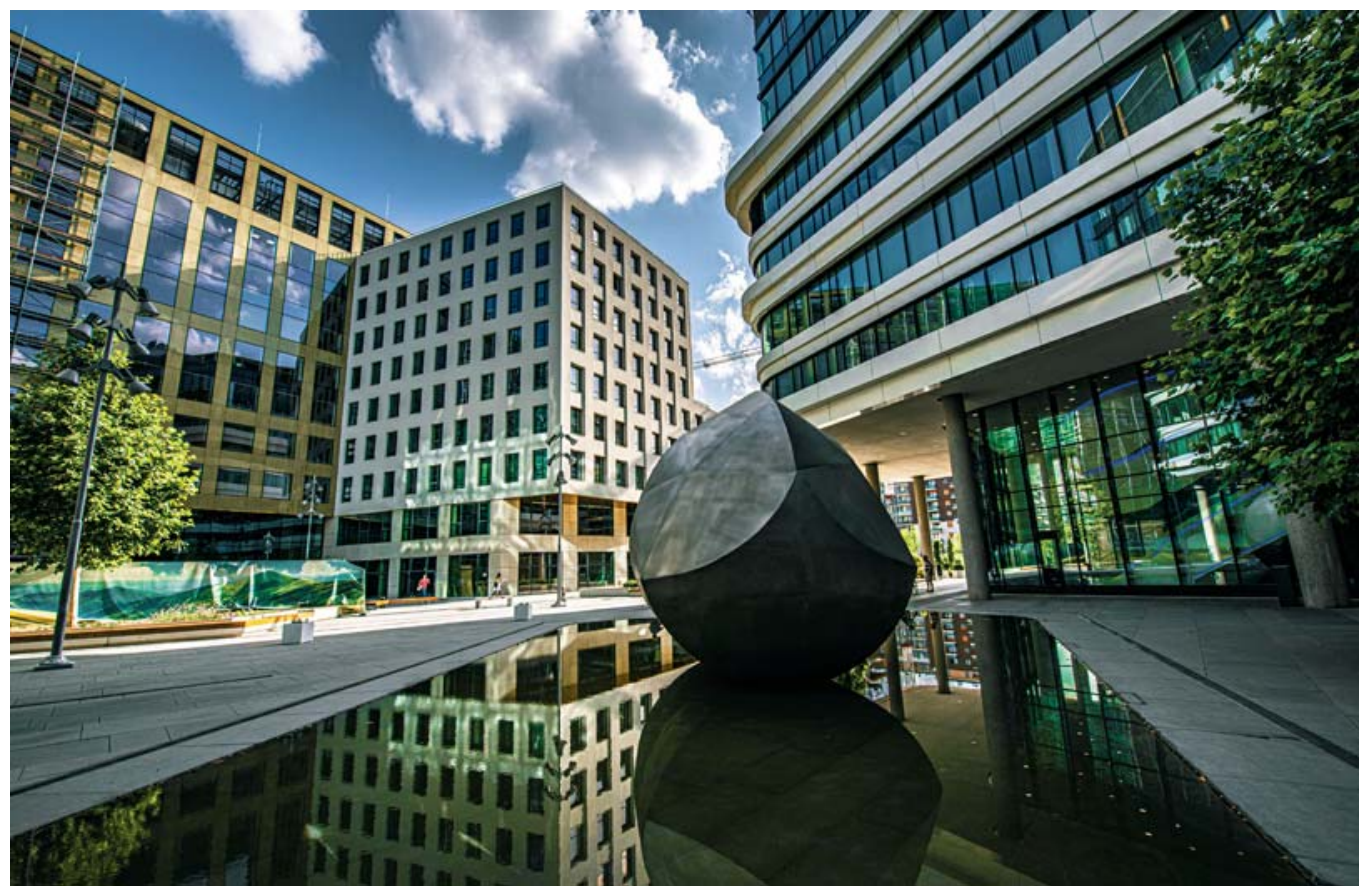

mai standardoknak, míg a mellékutcákban található épületek nagy többsége nem. A házak többségükben leromlott szerkezetűek voltak, sok közülük életveszélyes állapotban, a lakások közel 50\%-a nem rendelkezett WC-vel, 40\%-a fürdőszobával, a lakások 65\%-ában csak egy szoba volt.

Az önkormányzat az előkészítés során - tekintettel a különleges elvárásokra, a belvárosi környezetre és a városfejlesztés közösségi felelősségére - több építészeti workshopot és két országos, nyilvános építészeti tervpályázatot is rendezett a magyar építészszakma véleményének megismerése és az építészeti minőség megteremtése érdekében. Az önkormányzat és a Rév8 a pályázatok eredményéből ajánlásokat készített a befektetői tenderen indulóknak.

A befektetői tendert elnyerő Futureal a belépésekor folytatta a felelős, közös gondolkodást, neves hazai és nemzetközi szakembereket vontak be a koncepció véglegesítésébe.** Ebben az időszakban a Harvard Egyetem Posztgraduális Építészeti és Várostervezési Iskolájának [19] egy féléves stúdiuma foglalkozott a terület beépítésével Rodolfo Machado**** építészprofesszor veze-

\section{Az eredmények}

Egy nagy városfejlesztési projekt eredményeit több szinten lehet értékelni. Ben Brownlee egy érdekes szempontsort vetett fel a projektek értékeléséhez [23], a Sydney-i Operaház fejlesztésének példáján. Azt vizsgálta, hogy sikeres volt-e a projekt. Azt állítja, hogy „elsőre úgy tűnik, hogy nem, mert az eredeti költségbecslés 15-szeresét fordították rá, és a tervezett határidőt nyolc évvel lépték túl. De az elvárt eredmény, hogy nemzeti jel és karakter szülessen, sikerült, Sydney felkerült a térképekre. A projekt tehát sikeres." Egy projektek menedzselésével foglalkozó brit szakcikk szerint egy projekt akkor sikeres, ha eléri céljait, ehhez tartja a kitüzött idó és pénzügyi kereteket. [22] Nézzük ezeket a szempontokat a Corvinprojekt esetében.

2000-ben a program kitalálásakor és megindításakor az önkormányzat és a Rév8 megfogalmazták, hogy milyen eredményeket várnak a projekttől, mit tekintenek sikernek. A döntés megfogalmazott társadalmi, gazdasági és környezeti értékeket, amelyek teljesülését most, húsz év után érdemes áttekinteni. A 2003-ban megkötött együttmúködési szerződésben tízéves határidőt rög- 


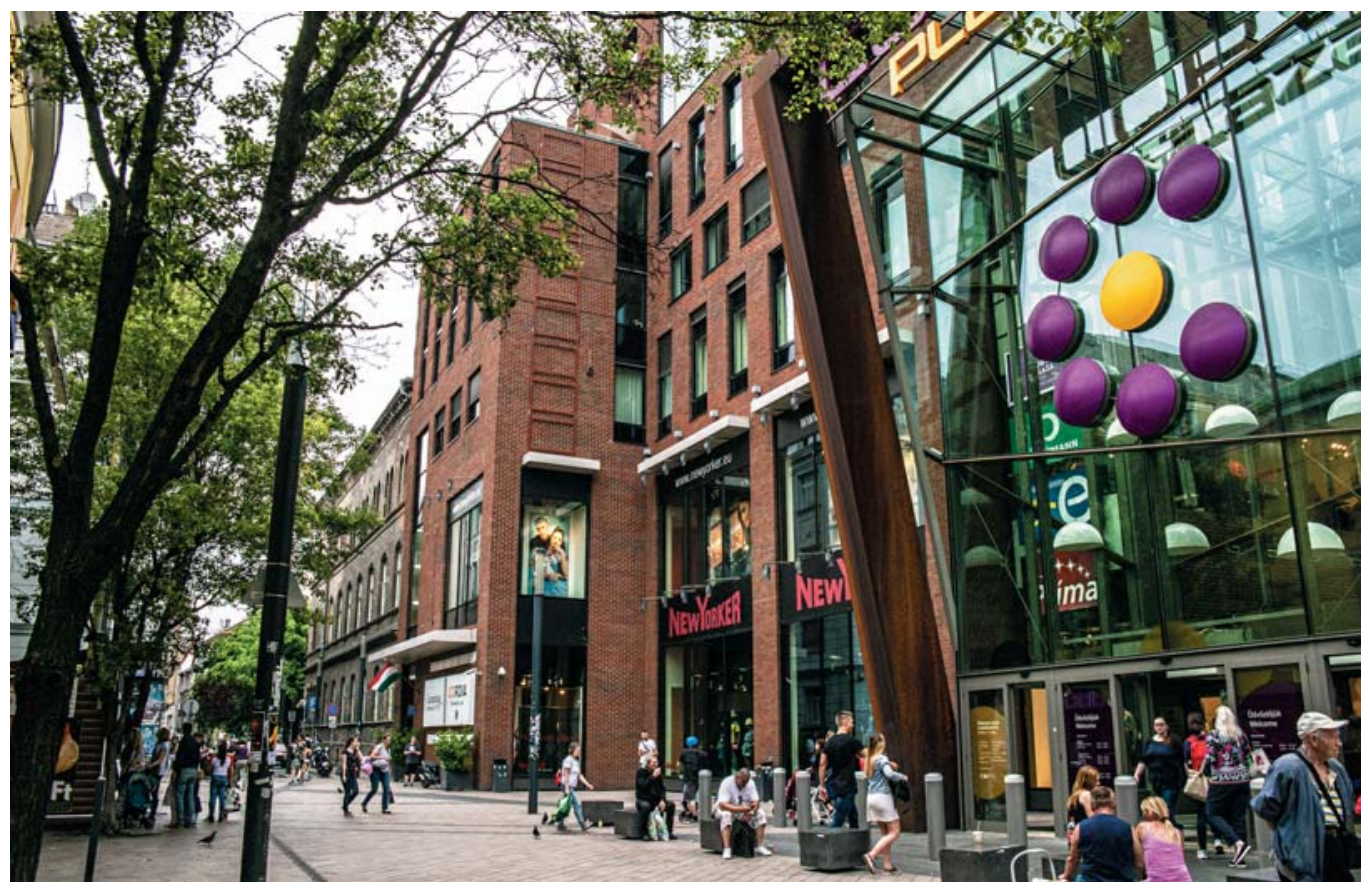

zítettek, de a 2009-től zajló ingatlanpiaci válság szétzilálta ezeket a határidőket. Mind az önkormányzat teljesítései, mind a befektető piaci körülményekhez illesztett építkezései lelassultak. Ugyanakkor a projekt sikerét, a Futureal szakmai munkáját és elkötelezettségét is jelzi és jelenti, hogy a válság idején csak lelassult, és utána új erőre kapva ma már Budapest egyik ingatlanpiaci sikerterméke. Az önkormányzati teljesítések megtörténtek, az utolsó épületek építése indult meg.

A kezdeti pénzügyi tervek 15 Mrd forintos önkormányzati költséggel - önkormányzati feladatok költsége, lakók elhelyezése, terület-előkészítés, közmü- és közterületi költségek - számoltak, amelyet három forrásból saját költségvetés, fővárosi-állami támogatás, befektetői telekbevétel - tervezett finanszírozni a kerület, a három forrás közel egyenlő megoszlásával. A 2016-os számítások szerint a valós költségek elérik a 20 Mrd forintot.

A költségek finanszírozása is módosult, mert a kerület és a befektető 40-40\%-ban, míg a Főváros és a Magyar Állam 20\%-ban vett részt benne. A teljes büdzsét kiegészítette a befektető partner által átvállalt közterületi munkák költsége, illetve az önkormányzat számra az általa épített lakások eladásából származó bevétel, valamint az önkormányzat vagyonnövekedése is. A költségek 60\%-a - az eredeti tervek szerint is - a lakók elhelyezésére fordítódott. Mivel a befektető tervezett beruházásai elérik a 180 Mrd forintot, az önkormányzati költségekre vetített multiplikátorhatás 9-szeres. A fenti szempontok szerinti értékelés alapján a költségek nőttek 25\%-kal, míg a határidő az eredeti 10-ről 17 évre nőtt, ugyanakkor a Corvin Sétány Program visszahelyezte Józsefvárost a térképre, teljesítette az alapvető elvárást. De nézzük részletesen is az eredmények alakulását.
Az egyik legfontosabb és a sikert biztosító elem a lakásprogram volt. A projekt legfontosabb vállalása az egész kerület megújításának megindítása és az itt élők lakáskörülményeinek javítása volt, hogy a lakóknak esélye legyen a kor színvonalának megfelelő lakáshoz jutni. Az önkormányzat a több mint 700, átlagosan 34,2 m²-es, több mint 65\%-ban 1 szobás, 40\%-ban komfort nélküli, és szintén mintegy 40\%-ban vizes, leromlott lakását bontotta le, és helyette közel 400 darab 100\%-ban összkomfortos vagy komfortos, átlagosan $42 \mathrm{~m}^{2}$-es lakásokat szerzett be a lakók elhelyezésére. 2009-ig a projekt sikerét a szereplők közötti bizalom, az értékek következetes megtartása, a programok iránt történő elköteleződés, a munkatársak szociális érzékenysége adta. A szereplők közötti kapcsolat teremtette meg az integrált programok sikerességét, hiszen a legfontosabb, legnehezebb tevékenység a különböző érdekeket képviselő szereplőkkel történő együttműködés biztosítása volt úgy, hogy a program célkitüzései, értékei és a tulajdonosi elvárások ne sérüljenek.

A projekt eredményeként teljesült az a célkitüzés is, hogy Józsefváros kerüljön be a fővárosban keresett lakóhelyek közé. A program megvalósulásával kapcsolatban 2003 óta a kerületi ingatlanok keresetté váltak, az elmúlt években az ingatlanválság után a budapesti átlag felett nőtt az ingatlanok értéke különböző mértékben mind a környező tömbökben, mind a kerület egészében. Az üres telkek értékesítési árának a szomszédos kerületekben tapasztalhatónál nagyobb mértékü növekedése komoly eredményt hozott az önkormányzatnak. [14] A program a korábban a kerület nem felfedezett részein is eladhatóvá tette a telkek és a lakások nagyobb részét. A program pozitív imázsa, az önkormányzat és a bon- 
tandó lakásért pénzbeli térítést kapó tulajdonosok/bérlők által bonyolított cserelakás-felvásárlások a kerületi lakásingatlanoknak az általános tendenciáknál erősebb felértékelődését eredményezték. A 2002-ben még 10 ezer darabos önkormányzati lakásvagyonnak a programhoz viszonyított területi elhelyezkedése függvényében mintegy 40\%-át alapvetően érintette ez a hatás. A fejlesztési terület vonzáskörzetében javult a befektetői klíma, új vállalkozások, kiskereskedelmi egységek jelentek meg, adó- és járulékbevételeket eredményezve. A program megvalósítása során 8000 új munkahely létesült. Ez csökkenő munkanélküli-támogatásokat és növekvő járulékbevételt eredményezett. [14]
Magdolnanegyed programmal együttesen jelent meg, [16] a piaci és a szociális városrehabilitáció egységében megtaláltuk azt az egyensúlyi pályát, amelyen a józsefvárosi kerületfejlesztés egyáltalán elindulhatott". [14] Látva az eltelt évek eredményeit, a cserelakásban elhelyezett családok új lakáskörülményeit, a program kidolgozóinak véleménye szerint „valódi szociális lakásprogram valósult meg". [14]

A városrész fejlődése tehát elindult. Napközben és esténként a környékbeliek, az itt dolgozók és az itt lakó fóleg bérlők látható elégedettséggel veszik birtokba az új sétányt és a szolgáltatásokat. A projekt és a közvetlen környék lakásai keresettek, az ingatlanpiac visszaigazol-

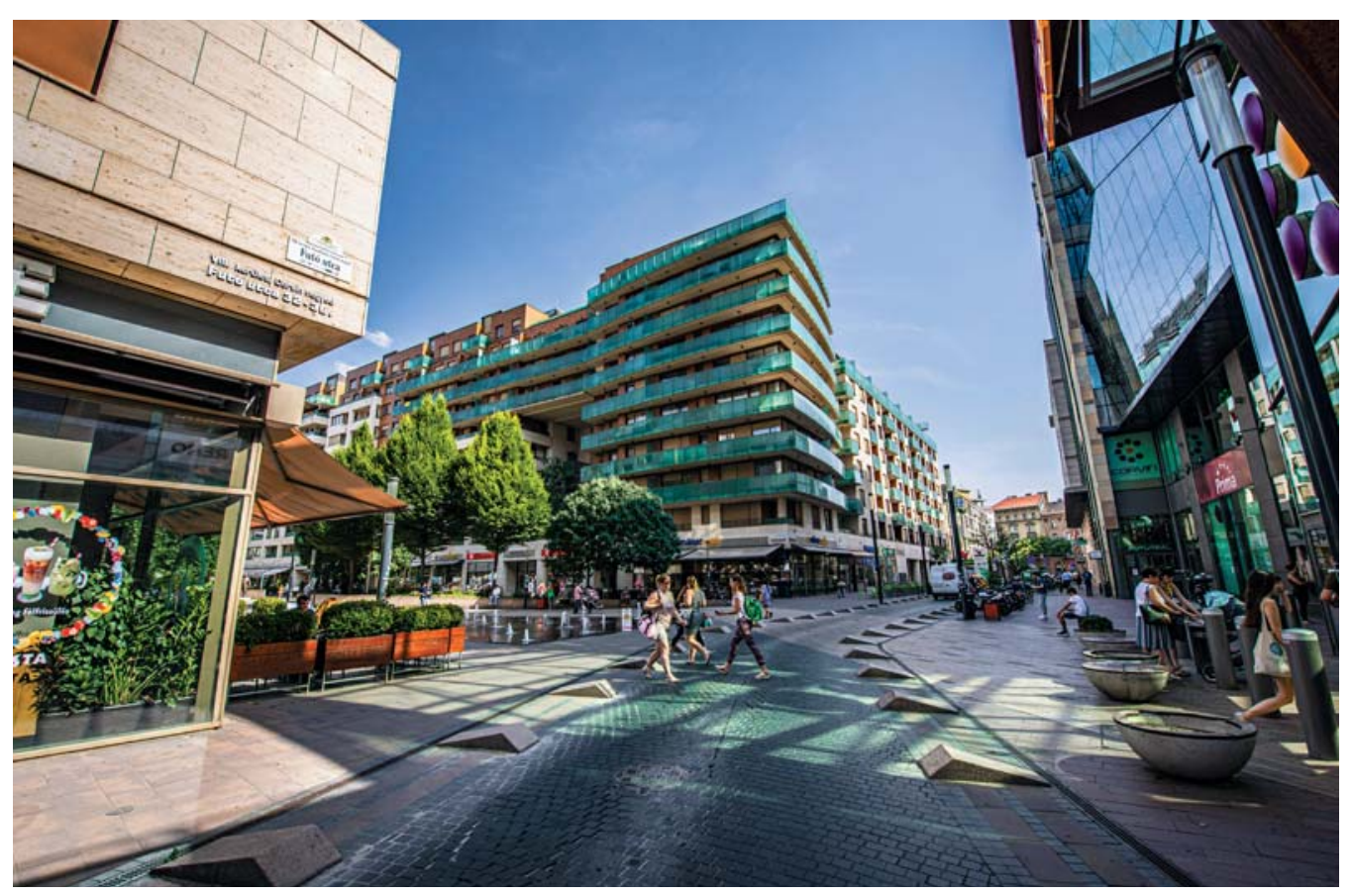

A program eredményeképpen alakult ki a kb. 1,5 hektár új közterület is, amelyből 1 hektár a három szakaszból álló Corvin sétány. A sétány beszövődik a kerületi egységes gyalogoshálózatba, amely a Kálvin térről indul, és egyrészt eljut a Teleki térig, másrészt a Corvin sétányon át a Klinikákig, és a Corvin moziig. Az önkormányzat a program keretében a közmúhálózat cseréjét és a meglévő közterületek felújitását végezte el a Futureallal kötött településrendezési szerződések keretei között, közel 1,5 Mrd forint értékben.

A Futureal mintegy 4000 lakást épített, illetve épít a projekt kereti között, és közel $50000 \mathrm{~m}^{2}$ irodaterületet, illetve további $40000 \mathrm{~m}^{2}$ üzleti, szolgáltatási felületet. Az irodaházakban és a megtelepült szolgáltatási szektorban kb. 8000 új munkahellyel lehet számolni. Az elkészült épületek minősített „zöld” épületek.

A Corvin Sétány Program az elmúlt 20 év alatt láthatóan segítette a józsefvárosi változásokat. A projekt az 1995-ben megszületett kerületfejlesztési koncepcióban a ja a várakozásokat. De a környezeti állapotok - utcák, terek, házak - a sétánytól alig egy utcára még sajnos keveset változtak, élesek a határok. Az összenövés hosszú folyamat, nincs áthatolhatatlan fal - nem lakópark épült. Ma is aktuálisak a tíz éve írt kérdéseim. [9] „Sikerül-e a sétánynak hellyé válnia, befogadja-e a város? Meg tudja-e tartani, és fokozni sokszínűségét, megmaradni nyitottnak, befogadónak és nem kirekesztőnek, hogy izgalmas hely legyen?"

\section{Alföldi György}

\section{Irodalom/References}

[1] Alföldi, György - Sárkány, Csilla: Corvin Sétány Projekt: Integrált városrehabilitációs projekt, Budapest 2002.

[2] Alföldi, György - Sárkány, Csilla - Rév8: „Az önfenntartó város koncepciója", Épitési Piac, No 11 (2002), pp 40-47. 


\section{Tervezők:}

Archiflex Stúdió; Archimago;

Bálint és Társa Építészek Irodája;

Bánáti és Hartvig Építész Iroda;

CET Budapest; Citinvest;

Fernezely, Basa Iroda

Építészműterem; Első Magyar

Építési Rt. Építőművészeti és

Mérnöki Iroda; Erick van Egeraat

Associated Architects Budapest;

Építész Stúdió; Finta és Társai

Építész Stúdió; Harvard Graduate

School of Design; In-Ex Stúdió;

INVI Investment Environments;

Közti Zrt.; LAND-A Táj- és

Környezettervezési Műterem;

Lukács és Vikár Építészstúdió;

MádiLáncos Stúdió; Mérték

Építészeti Stúdió; M-Teampannon

Építész és Mérnöki Iroda; Pálffy

Építész Iroda; Platinum; RÉV8;

Roeleveld-Sikkes Architects

Hungary; Stúdió 100; Spora

Architects; Tanos és Vonnák

Építész Stúdió; Theycom

Művészeti és Építész Iroda;

Townshend Landscape

Architects; Új Irány Csoport;

Vadász és Társai Építőművész Kft.;

Városi Tájkép Csoport; Zoboki,

Demeter és Társaik Építésziroda
[3] Alföldi, György: „A rendező változata”, Magyar Narancs, Vol 17, No 45, p 15.

[4] Alföldi, György - Sárkány, Csilla - ifj Erdősi, Sándor Molnár, György - Horváth, Dániel: Józsefváros

Magdolnanegyed Szociális Városrehabilitáció Program 2005-2008, pp 1-25.

[5] Alföldi, György - Sárkány, Csilla - Molnár, György - Horváth, Dániel - ifj Erdősi, Sándor: Józsefváros, Magdolnanegyed Programok 1-3 ütem, 2005-2016, Rév8.

[6] Alföldi, György - Somlyódy, Nóra - Szemerey, Samu -

Pásztor, Erika Katalina (eds): „Értelmiségi könnyek nélkül: In terjú Alföldi Györggyel, a Rév8 Rt vezérigazgatójával a Corvin sétányról, Épitészfórum, 2005-03-29.

[7] Alföldi, György: „Építészszerepek a városfejlesztésben, Budapest-Józsefváros, Futó utca megújítása", DLAértekezés, BME Építőművészeti Doktori Iskola, Budapest, 2007.

[8] Alföldi, György: „Szociális rehabilitáció a Józsefvárosban", Falu Város Régió, № 2 (2008), pp 27-34.

[9] Alföldi, György: „A változás igénye: Még egyszer a Corvin Sétányról", Magyar Narancs, Vol 22, No 8, pp 22-23.

[10] Alföldi, György: „Urban Quartett, A városszövet és a társadalmi szövet kölcsönhatása", in Benkő, M - Szabó, Á

(eds): Városmegújítás, BME Urbanisztika Tanszék, Budapest 2010.

[11] Alföldi, György: „Egy utca átváltozásai, Budapest-Józsefváros, Futó utca a 18 század közepétől a 21 század elejéig", in Veöreös András (ed): Kortárs épitészettörténet Il: Emlékkonferencia a 75 éves Winkler Gábor emlékére, 2018, p 63. [12] Jacobs, Jane: „Design Cities", in Gopnik, Adam: „Cities and Songs", The New Yorker, 2004-05-17.

[13] Molnár, György: „Az elmúlt huszonév 2, Fejezetek a józsefvárosi kerületfejlesztés történetéből" [blog], in A mi Józsefvárosunk blog, 2013, hozzáférhető: <https://mijozsefvarosunk.blog.hu/2013/04/07/11_az_elmult_huszonev> [utolsó belépés: 2019-10-31].

[14] Molnár, György: „A Corvin Sétány Program társadalmi költség-haszon elemzése" [kézirat], Budapest, 2009.

[15] Koszorú, Lajos - Alföldi, György - Sárkány, Csilla: Józsefvárosi Rehabilitációs Stratégia, Teampannon/Rév8, Budapest, 1998.

[16] Molnár, György - Echter, István - Iván, Andrea - Juharos, Róbert: Kerületfejlesztési koncepció (1995), Budapest. [17] Sárkány, Csilla: Józsefvárosi lakáskoncepció, Budapest 2001.

[18] Pásztor, Erika Katalina: „A politikai akarat ad többletet a város fejlődéséhez", Épitészfórum, 2002-12-19.

[19] Correa, Felipe: Provoking a New Form of Urbanity: The Corvin Promenade, Budapest, Cambridge, Massachusetts, 2005.

[20] Kiss, Daniel: Modelling Post-Socialist Urbanization, The Case of Budapest, Birkhauser, Basel 2018.
[21] Van Tuijl, Erwin - Van Haaren, Jeoren - Van den Berg, Leo: „From ghetto to mixed use knowledge quarter, The Corvin Promenade as catalyst for change in Budapest's VIIIth district" Rotterdam: EURICUR, Erasmus University Rotterdam, 2011, p 50.

[22] Matthews, Dan: „Flexibility is key in project delivery”, Raconteur, 2015-08-02, hozzáférhető: <https://www.raconteur.net/project-management-2015> [utolsó belépés: 201910-31].

[23] Brownlee, Ben: „Right projects in the right way”, Raconteur, 2013-07-08, hozzáférhető: <https://www.raconteur.net/project-management> [utolsó belépés: 2019-1031].

[24] UrbanLand Editorial: „Corvin Promenade, BudapestHungary", ULI Global Awards for Excellence Urban Land, No 3 (2015), pp 78-79.

\section{Megjegyzések}

* Rév8 Rt., Józsefvárosi Rehabilitációs és Városfejlesztési Részvénytársaság. A Józsefvárosi Önkormányzat 50\%-0s, a Fővárosi Önkormányzat 39\%-os és az OTP Bank 11\%-os tulajdonosi részesedésével alakult meg a társaság. A Józsefvárosi Önkormányzat 2000-ben kivásárolta a Rév8 Rt.-ből az OTP Bankot.

** 2004 júliusától szeptember végéig volt több workshop, amelyekbe a Futureál bevont egy francia szakembert, Guy Perryt, aki a Harvard Graduate School of Designon (www.gsd.harvard.edu) tanít ingatlanfejlesztést, mellette részt vett Finta József, Meggyesi Tamás, Benkő Melinda és Lukovich Tamás.

*** Rodolfo Machado, Harvard Graduate School of Design, az Urban Planning and Design Tanszék vezetője.

**** A pályázatot az angol tájépítész, Robert Townsend nyerte.

Fotók: Futureal 


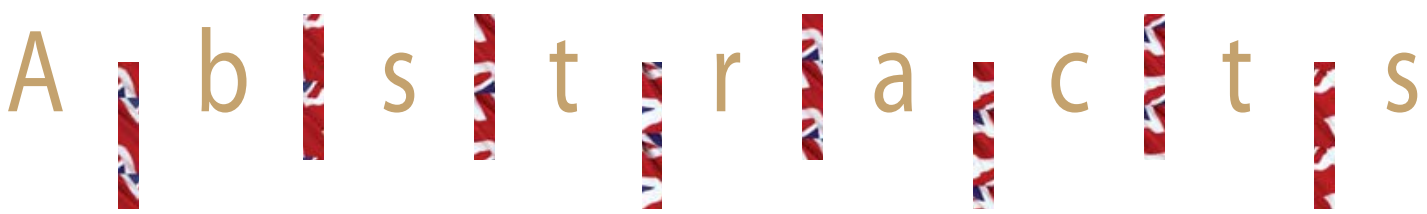

MIZSEI, Anett: STARSHIP MOORED BETWEEN THE AGES Citation: Metszet, Vol 10, № 6 (2019), pp 12-21, DOl: 10.33268/Met.2019.6.1 PUSKÁS ARENA, BUDAPEST, HUNGARY ARCHITECTS: GYÖRGY SKARDELLI AND KÖZTI

Retaining the architectural spirit of this stadium's predecessor (the People's Stadium) a new structuralist monument has been developed placing Hungary at the forefront of sports innovation. In recent decades the tendency to start with a clean slate has resulted in architectural won ders, but at what cost to cultural identity? Here is a stadium that has dire links to its past, by means of partial restoration, and the act of reinstating the previous building's supporting structures. The latter being reinforcec concrete pylons which house the access stairs, lifts and serve as the mair support system to the building itself. Sport as in any activity forms part 0 a nation's identity and this stadium has succeeded in representing this fact.

\section{ZÖLDI, Anna: MASS HOUSING IN THE 21ST CENTURY} Citation: Metszet, Vol 10, № 6 (2019), pp 22-25, DOI: 10.33268/Met.2019.6.2 SEESTADT ASPERN, VIENNA, AUSTRIA ARCHITECT: TOVATT ARCHITECTS \& PLANNERS

On the outskirts of Vienna one of Europe's largest urban development projects can be found. The goal being to create a model example of how to establish a "smart city". This has been designed to be organic in nature, offering a positive approach to the urban experience, where residents can live in secure surroundings. The ideals of an optimum work-life balance are met integrating places of employment alongside homes, parks and public transport networks. Continual monitoring of the development's use patterns should assists evaluation of environmental impact and general facility management.

\section{WARE-NAGY, Orsolya: INPSIRED FRAMEWORK}

\section{Citation: Metszet, Vol 10, No 6 (2019), pp 26-29, DOI: 10.33268/Met.2019.6.3}

TWO TOWERS NURSERY AND KINDERGARTEN, PARIS, FRANCE

ARCHITECTS: QUERKRAFT and SAM ARCHITECTURE

As part of the Clichy-Batignolles EcoDistrict project established to redevelop industrial wasteland and integrate Paris' bid for the 2012 Olympic Games several residential and commercial buildings were realised.

Amongst these is a development of two towers, linked at ground and first floor level, by a nursery school and kindergarten. A complex development to provide social housing, education and commercial space on building volume.

\section{SÁGHI, Attila: EXCELLENT COOPERATION}

Citation: Metszet, Vol 10, No 6 (2019), pp 32-35, DOI: 10.33268/Met.2019.6.4 NATIONAL MUSEUM RESTORATION AND STORAGE CENTRE (OMRRK), BUDAPEST, HUNGARY

ARCHITECTS: ZSOLT VASÁROS, NARMER ARCHITECTURE STUDIO

One of the most important elements of the Budapest Liget project is the brownfield development of a former hospital. It was deemed necessary to develop a centre for the restoration and storage of artefacts for future museums. Regeneration of the former hospital site lead to the decision to invest in renewable energy and environmental protection. This facility also serves to support the Artpool, Fine and Applied Arts lectorate archives, making it a leading source for research documents in Central Europe.

\section{ALFÖLDI, György: BIRTH OF A NEIGHBOURHOOD}

Citation: Metszet, Vol 10, № 6 (2019), pp 36-44, DOI: 10.33268/Met.2019.6.5

JÓZSEFVÁROS URBAN REHABILITATION PROJECT, BUDAPEST, HUNGARY Urban rehabilitation takes on many forms ranging from radical change of use to the more questionable act of gentrification. In Budapest's Józsefváros the pressing issues of poverty and inadequate housing had to be addressed. Replacing housing alone would not suffice, therefore development of a more complex urban situation was required, offices, shops and an improved infrastructure had to be planned. Eventually 4000 homes, $50,000 \mathrm{~m}^{2}$ of commercial space and $40,000 \mathrm{~m}^{2}$ retail was developed.

\section{BECKER, Gábor: A 150 YEAR-OLD WORKSHOP}

\section{Citation: Metszet, Vol 10, No 6 (2019), pp 46-55, DOI: 10.33268/Met.2019.6.6}

A HISTORY OF BME DEPARTMENT OF BUILDING CONSTRUCTIONS

A history of how the Department of Building Constructions was established at the Technical University of Budapest. Starting at the point where architecture as an art was partnered with structural engineering as a discipline for the mathematical (analytical and geometrical), mechanical and chemical development of building structures. Dealing with changes in political influence, teaching methods and members of the professional teaching staff.

\section{MEDVEY, Boldizsár - DOBSZAY, Gergely: DURABILITY OF SOIL BASED EXTERNAL WALLS}

Citation: Metszet, Vol 10, No 6 (2019), pp 56-63, DOI: 10.33268/Met.2019.6.7

As the contemporary trend for developing buildings with external earth walls increases the need to measure rates of stability, structural integrity and therefore durability has grown. Guidelines for developing these methods of construction follow research into contemporary design trends, knowledge of regional construction methods, chemical analysis, selection of suitable base materials and a harmonisation of test methods. Once these areas of study have been undertaken suitable advice into how to build against erosion can be offered.

\section{HORVÁTH, Sándor: BALCONIES, LOGGIAS, TERRACES DRAINAGE, AND HANDRAIL FIXING}

Citation: Metszet, Vol 10, № 6 (2019), pp 64-69, DOl: 10.33268/Met.2019.6.8

When designing external spaces to buildings such as balconies and the like, critical problems may occur due to poor detailing. Although current discussion focuses on the problems created by thermal bridging little attention is paid to drainage problems, snow loading and surface treatment, all of which might lead to structural failure. The same applies to the design of handrails, as a safety measure, and how to integrate these with surface water drainage solutions. "The Devil in the Details" really does apply to this area of building design requiring that multidisciplinary cooperation in a necessity to avoid failure. 